\title{
Development of a Safety protocol for Management Thirst in the Immediate Postoperative Period*
}

\author{
ELABORAÇÃO DO PROTOCOLO DE SEGURANÇA PARA O MANEJO DA SEDE NO \\ PÓS-OPERATÓRIO IMEDIATO
}

DISEÑO DEL PROTOCOLO DE SEGURIDAD PARA EL MANEJO DE LA SEDE EN EL
POSOPERATORIO INMEDIATO
Leonel Alves do Nascimento ${ }^{1}$ Lígia Fahl Fonseca² Edilaine Giovanini Rosseto² Claudia Benedita dos Santos ${ }^{3}$

\begin{abstract}
Objective: To develop a safety protocol for the management of thirst in the immediate postoperative period. Method: Quantitative, methodological, and applied study conducted in April-August 2012. An extensive literature search and expert consultation was carried out to develop the protocol and its operating manual. Theoretical and semantic analyzes were carried out by experts. Results: Assessment of level of consciousness, reflexes of protection of the airways (cough and swallowing), and absence of nausea and vomiting were selected as safety criteria. These criteria were grouped and formatted in a graph algorithm, which indicates the need to interrupt the procedure if a security criterion does not reach the expected standard. Conclusion: The protocol was elaborated to fill in the gap in the literature of a specific model concerning nursing actions in the safe management of thirst in the immediate postoperative period.
\end{abstract}

\section{RESUMO}

Objetivo: Elaborar um protocolo de segurança para o manejo da sede no pósoperatório imediato. Método: Pesquisa metodológica e aplicada, quantitativa, desenvolvida nos meses de abril a agosto de 2012. Para a elaboração do protocolo e seu manual operacional, efetuou-se uma extensa busca na literatura e consulta a especialistas. As análises teórica e semântica foram realizadas por juízes. Resultados: Os critérios de segurança elencados foram: avaliação do nível de consciência e dos reflexos de proteção de vias aéreas (tosse e deglutição) e ausência de náuseas e vômitos. Esses critérios foram agrupados e formatados num algoritmo gráfico, que conduz à interrupção do procedimento caso um critério de segurança não alcance avaliação esperada. Conclusão: A construção do protocolo visou suprir a falta de um modelo específico na literatura para padronizar as ações de enfermagem no manejo da sede no pós-operatório imediato com segurança.

\section{RESUMEN}

Objetivo: Diseñar un protocolo de seguridad para el manejo de la sede en el posoperatorio inmediato Método: Investigación metodológica y aplicada, cuantitativa, desarrollada en los meses de abril a agosto de 2012. Para la confección del protocolo y su manual operacional, se llevó a cabo una extensa búsqueda en la literatura y consulta a expertos. El análisis teórico y el semántico los realizaron los jueces. Resultados: Los criterios de seguridad enlistados fueron: evaluación del nivel de conciencia y de los reflejos de protección de las vías aéreas (tos y deglución) y ausencia de náuseas y vómitos. Dichos criterios fueron agrupados y formatados en un algoritmo gráfico que conduce a la interrupción del procedimiento en caso de que un criterio de seguridad no alcance la evaluación esperada. Conclusión: La construcción del protocolo tuvo el fin de suplir la falta de un modelo específico en la literatura para estandarizar las acciones de enfermería en el manejo de la sede en el posoperatorio inmediato con seguridad.

\section{DESCRIPTORES \\ Sed \\ Protocolos clínicos \\ Cuidados postoperatorios \\ Enfermería perioperatoria}

$\begin{array}{ll}\text { DESCRIPTORS } & \text { DESCRITORES } \\ \text { Thirst } & \text { Sede } \\ \text { Clinical protocols } & \text { Protocolos clínicos } \\ \text { Perioperative care } & \text { Cuidados pós-operatórios } \\ \text { Perioperative nursing } & \text { Enfermagem perioperatória }\end{array}$

\footnotetext{
* Extracted from a dissertation entitled "Elaboração, validação e fidedignidade de um Protocolo de Segurança para o Manejo da sede no Pós-Operatório Imediato"; Londrina State University, 2013. "MSc student, Graduate program in Nursing, State University of Londrina, Londrina, PR, Brazil. ${ }^{2}$ Adjunct Professor, Department of Nursing, State University of Londrina, Londrina, PR, Brazil. ${ }^{3}$ Associate Professor, School of Nursing of Ribeirão Preto, University of São Paulo, WHO Collaborating Centre for the Development of Nursing Research, Ribeirão Preto, SP, Brazil.
} 


\section{INTRODUCTION}

Thirst is a high-incidence discomfort in the immediate postoperative period (IPO), which causes suffering to patients during their recovery from anesthesia. Thirst is defined as a conscious desire to drink water and is a compensation mechanism, so that the organism has its water balance restored. Thirst is conditioned by both physiological signs and symptoms and cultural, emotional, habitual, and food conditions ${ }^{(1)}$

Surgical patients present conditions that promote and enhance the appearance of thirst, including preoperative fasting, medication in the anesthetic-surgical process, endotracheal intubation and intraoperative blood loss ${ }^{(2)}$.

Patients have reported that they nearly died of thirst during the postoperative period of cardiac surgery when asked about their memory of anesthetic recovery ${ }^{(3)}$. In a study $(n=160)$ during IPO, many patients $(43.8 \%)$ indicated that thirst was the discomfort with the highest incidence $^{(4)}$. In other studies, occurrences ranging from $42.9 \%$ $(n=91)^{(5)}$ to $75.0 \%(n=128)^{(6)}$ were mentioned. During this period, intensity of thirst is also high. When a numeric analog scale ${ }^{(1-10)}$ was utilized to evaluate thirst, patients indicated a mean intensity of $6.1(\mathrm{SD}=2.2)^{(6)} 6.6(\mathrm{SD}=2.0)^{(5)}$ and $8.2(S D=1.5)^{(7)}$.

In the evaluation of strategies to alleviate the discomfort of thirst during recovery from anesthesia, administration of ice chips proved to be more effective in the relief ${ }^{(6-8)}$. Thirst in patients in the perioperative period is a sign and symptom of imbalance and intense discomfort, which should be valued and assisted by the staff.

Despite the magnitude of thirst, it has however been considered a minor complication in the perioperative period and its impact on patients is poorly studied. Too often, health professionals allow patients to remain thirsty for extended periods in both pre and postoperative periods. When interventions are performed, they are sporadic and occasional, assistematic and empirical.

The approach in the management of thirst, especially in IPO, has particular challenges due to the contraindication to oral intake of large liquid volumes since pulmonary aspiration is possible due to a decrease in the level of consciousness by both anesthetic drugs and presence of nausea and vomiting. Therefore, finding safe ways to alleviate thirst that has already set in when patients arrive at the PACU without putting their safety at risk, is themajor issue.

Emphasis on the safety of the surgical patient (including detailed protocols of the WHO) and implementation of strategic plans (such as Safe Surgeries Save Lives) have significantly reduced the errors in perioperative care ${ }^{(9)}$. Amongst safety standards proposed by specialized associations for assessment and release of patients emerging from anesthesia are parameters such as level of consciousness, airway patency, respiratory rate, oxygen saturation, blood pressure, pain, nausea, and vomiting ${ }^{(10)}$. However, no recommendation or assessment protocol was found in the literature focusing safety in the use of strategies when thirst has already set in and has been identified. Consequently, it remains not assessed, recorded ormet. The team who assists patients in the IPO does not act in the presence of thirst because they do not know how to do it for lack of stablished criteria and, consequently, fear of increase of complications risks.

Preparation of a Safety protocol for Thirst Management (SPTM) will contribute to raising the level of safety in the care of thirsty patients. The SPTM will allow health professionals to systematically assess clinical condition of patients with subsidies to decide whether a method of relief should be administered or not.

\section{METHOD}

This is a methodological and quantitative-approach study, which was conductedin the period April-August 2012 in association with the Group for Study and Research on Thirst (GSRT), State University of Londrina, Southern Brazil, seeking to understand and investigate the complexity of perioperative thirst. Methodological studies are characterized by the development of instruments for data collection, definition of the construct (behavior to be measured), formulation of items of the tool, and formulation of instructions for users and respondents ${ }^{(11)}$.

The protocol for preparation of instruments was based on the theoretical model and terminology proposed by Pasquali ${ }^{(12)}$, and was used in measuring subjective phenomena, with emphasis on the theoretical procedures.

Although thirst is controlled by complex neurohormonal factors, perception and response to them are strongly influenced by environmental, cultural, and psychological factors, resulting in a multifactorial symptom manifested in an individual and subjective way ${ }^{(1-2)}$. As a specific model for construction of protocols was not found in the literature, the psychometric-based method of Pasquali was chosen due to the methodological rigor proposedby the author. Psychometry has the additional advantage of representing knowledge of nature more accurately than common language in describing observation of natural phenomena(12).

In the preparation of instruments for psychological measurements, the theoretical pole is the basis for all scientific endeavor, that is, to explicit the theory on the construct (pshychological object), for which both developing a measuring instrument and operationalizing it into items are necessary ${ }^{(12)}$. This pole allows clarifying the theory of latent trait and types (or categories) of behaviors that adequately represent the same trait. Theoretical procedures must be designed for each instrument; for this
Development of a Safety protocol for Management Thirst in the Immediate Postoperative Period Nascimento LA, Fonseca LF, Rosseto EG, Santos CB 
purpose, we rely on the existing literature on the psychological construct that the instrument will measure ${ }^{(12)}$.

The theoretical procedure shave six stages: psychological system, properties, dimensionality, definitions, operationalization, and theoretical and semantic analyses. The first three steps are related to the theory of the construct, the fourth stage includes both theory and construction of the instrument, and the fifth and sixth steps refer to the construction of the instrument ${ }^{(12)}$. The steps and corresponding activities of this study are shown in Figure 1.

\begin{tabular}{|c|c|c|c|}
\hline & \multicolumn{3}{|c|}{ Theoretical Procedures } \\
\hline 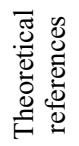 & $\begin{array}{c}1 \text { - Psychological System } \\
\text { Reflection and Interest } \\
\text { "Pasquali (1999)" }\end{array}$ & $\begin{array}{l}2 \text { - Definition of Property/Reflection, } \\
\text { interest and consulting the literature } \\
\text { "Pasquali (1999)" }\end{array}$ & $\begin{array}{l}3 \text { - Dimensionality of the Attribute and Definition } \\
\text { of Safety Criteria for Management of Thirst, } \\
\text { Literature, consultation with experts and } \\
\text { experience of investigators "Pasquali (1999)" }\end{array}$ \\
\hline 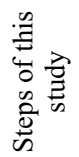 & $\begin{array}{c}\text { Definition of Construct/ } \\
\text { Systematization of existing } \\
\text { knowledge/Psychological } \\
\text { System: "Thirst" }\end{array}$ & $\begin{array}{l}\text { Definition of Property or Attribute / } \\
\text { Property: "Safety in the management } \\
\text { of thirst" }\end{array}$ & $\begin{array}{c}\text { Development of safety criteria for the } \\
\text { management of thirst }\end{array}$ \\
\hline 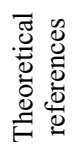 & $\begin{array}{c}4 \text { - Definitions } \\
\text { "Pasquali (1999)" }\end{array}$ & $\begin{array}{l}5 \text { - Operacionalization / Category of } \\
\text { behavior, literature, experience and } \\
\text { interviews "Pasquali (1999)" }\end{array}$ & $\begin{array}{l}6 \text { - Theoretical and Semantic Analysis } \\
\text { "Pasquali (1999)" }\end{array}$ \\
\hline 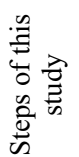 & $\begin{array}{l}\text { Constitutive Definitions } \\
\text { Operational Definitions }\end{array}$ & $\begin{array}{c}\text { Construction of items / Apparent } \\
\text { Validation / Development of SPTM } \\
\text { and Operational Manual }\end{array}$ & $\begin{array}{c}\text { Theoretical Analysis by Experts / Semantic } \\
\text { Analysis }\end{array}$ \\
\hline
\end{tabular}

Figure 1 - Graphical representation of activities performed during preparation of the Safety Protocol for Management of Thirst, as proposed by Pasquali ${ }^{(12)}$ in the theoretical pole - southern Brazil, 2013.

\section{STEPS 1-2 - Psychological system and definition of property}

Determination of the psychological system and definition of property are essential because they make explicit the theory on the construct being built ${ }^{(12)}$. In this study, reflection on the subject has stimulated the creation of a tool that would allow to measure safety criteria in the management of thirst in IPO. As a result, it was established that thirst refers to the psychological system and safety in the management of thirst in the IPO is the property attribute whose measurement is the subject of this study.

\section{STEP 3 - Dimensionality of the attribute and definition of safety criteria for the management of thirst}

Dimensionality of the attribute is related to its internal or semantic structure. The distinct components of safety criteria in the management of thirst that must be assessed to ensure safety are defined here ${ }^{(12)}$.

Definition of items assessed by the SPTM was based on the following sources of information: scientific literature, analysis of theoretical foundations, available evidence, expertise of investigators in patient care in the IPO, interview with professionals with clinical experience and knowledge added by the Group for Study and Research of Thirst of the State University of Londrina.
Extensive consultation was carried out in the Latin American and Caribbean Literature on Health Sciences (LILACS), Cumulative Index to Nursing and Allied Health Literature (CINAHL), PubMed, EMBASE, and The Cochrane Library databases, and the following descriptors were used: thirst, perioperative period, anesthetic recovery, nausea and vomiting, swallowing, postoperative complications, return of swallowing reflexes, complications in maintaining the airways and breathing ice, water, evaluation in IPO, airway patency, hydration of the mucosa, oral hydration, and discharge criteria in the post anesthesia care unit (PACU). Publications in books and inclusion criteria were: articles indexed in databases with descriptors selected in Portuguese, Spanish, and English since the 1980s.

In order to define these criteria, a convenient sample of experts $(n=18)$ was consulted, including anesthesiologists $^{(13)}$, surgeons ${ }^{(3)}$, and PhD nurses ${ }^{(2)}$. Inclusion criteria were: having experience in caring for patients in the IPO, act in medium and large size public and private hospitals in the city of Londrina, be accessible, agreeing to participate in the studyand sign the Term of Free and Informed Consent. For this purpose, they answered the following question: What are the criteria that, in your practice, you assessto release administration of a method for relief to patients who refer thirst in the PACU? The number of interviews with anesthesiologists was intentionally high be- 
cause this professional releases or not the administration a strategy for thirst relief in the IPO.

The leading thought for final selection of safety criteria was guided by the following question: What would be important to assess during recovery from anesthesia that could actually jeopardize patient safety? Responses were grouped by frequency, thus defining safety categories that werethen confronted withboth pertinent literature and experience of investigators. Knowledge gained by the GSRT was another relevant source of information during selection of criteria given the embryonic state of research of this subject.

\section{STEP 4 -Constitutive and Operational Definitions}

After the selection of safety criteria is ready, conceptualizing the constructs in detail is necessary. This step comprises a clear and precise conceptualization of the factors that matter in the construction of the measuring instrument ${ }^{(12)}$.

Constitutive definition is one that defines a construct using others constructs. It characterizes the construct, giving it the dimensions that it should havein the semantic space of the theory in which it is inserted ${ }^{(12)}$.

In turn, the operational definition representsa passage from abstract to concrete, and there are two main concerns, ${ }^{(1)}$ the definitions should be in fact operational, so that they can be reproduced by physical behaviors and (2) the definition of the constructs should be as comprehensive as possible. They come from the literature, opinion of experts, and knowledge of the investigator. The more complete the list of behavioral categories, the simpler the construction of the instrument will be ${ }^{(12)}$.

\section{STEP 5 - Operationalization}

This step is related to the construction of the items, to the to the expression of the behavioral representation of the construct, i.e., the actions the user of the instrument must perform to assess the magnitude of the presence of the construct ${ }^{(12)}$.

In order to build theresearch instrument it is necessary to take into accountthe following criteria: behavior, objectivity, simplicity, clarity, relevance, accuracy, variety, modality, typicity, credibility, amplitude, and balance ${ }^{(12)}$. These criteria guided the construction of the first version of the protocol, including six safety indicators and 16 evaluation items which were shownin a graph algorithm.

Then the Operational Manual was prepared, specifying the operations that must be executed to collect the information required and including the criteria for observation and measurement of the variable being assessed ${ }^{(11)}$. The structure of the Operational Manual was adapted from a study conducted to develop and validate an instrument for measurement of nursing carequality ${ }^{(13)}$. The manual consists of descriptor, scientific basis, assessment sources, operational procedures, and criteria for qualification and periodicity of assessment.

\section{STEP 6 - Theoretical and semanticanalysis}

The set of selected items that constitute the instrument, should indicate an adequate representation of the construct. In order to characterize the relevance of items, a theoretical and semantic analysis by judges is necessary.

\section{Theoretical analysis by judges}

The protocol items were analyzed by three PhD-prepared nurses with experience in the care of patients in the IPO, who evaluated that the structure of instrument and the item sin each proposed category were adequate.

These procedures assured that the choice of safety criteria was determined by its relevance, giving face validity to the SPTM. Apparent validity indicates whether, a priori, the measurement measures what it is supposed to measure. Even though it does not determine surely that the measurement scale is valid, it is fundamental in the development of the process, thus enabling other validation methods ${ }^{(12)}$. With this evaluation, the number of items are reduced, according to the decision of judges ${ }^{(14)}$.

\section{Semantic Analysis of the Safety Protocol for Thirst Management (SPTM)}

This analysis assesses the semantic structure of the items and the compatibility of writingto the level of the target population, allowing to check whether all items are understandable to all members of the population to which the instrument is intended ${ }^{(12)}$. The instrument should not require reading skill beyond that of a 12-years adolescent. This means that the items should be short and simple, without complicated words or jargon terms ${ }^{(14)}$.

This analysis was conducted at the University Hospital of Londrina (HUL), which is a tertiary-level, public teaching, and a reference institution for the Unified Health System (SUS), with 313 beds, one Surgical Center, and a PACU with seven beds. Eight health professionals were invited to participate in the analysis, being divided into two groups. The first group consisted of four nursing assistants, and the second of two MSc-studentand two PhD nurses. Both groups had experience in patient care in the PACU.

The SPTM was presented orally, item by item, to both groups in separate meetings. Participants were asked to reproduce the actions or content reported, recording them in a specific instrument. At this stage, some writing adjustments and spelling changes were made. Such changes were made after two rounds with the participants. It was possible to verify that the SPTM was well understood by both groups.

\section{Ethical procedures}

All steps of this study met the guidelines of the Legal Resolution No. 196 (10 Oct 1996). After the project was approved by the Ethics Committee of the institution where the study was conducted (CAAE: 02299412.6.0000.5231), all participants signed the term of written and informed consent.
Development of a Safety protocol for Management Thirst in the Immediate Postoperative Period Nascimento LA, Fonseca LF, Rosseto EG, Santos CB 


\section{RESULTS}

In this study, thirst was defined as psychological system and safety in the management of thirst as an attribute of property. From this point, establishing the dimensions and definitions of the protocol was possible. Consultation of 18 professionals with experience in IPO indicated the following safety criteria: assessment of consciousness level $(n=15)$, protection of the airways (cough and swallowing; $n=4)$, absence of nausea and vomiting $(n=3)$, oxygen saturation $(n=1)$, surgical procedure $(n=5)$, quantification of diuresis $(n=2)$, bowel sounds $(n=1)$, anesthetic technique $(n=1)$ and blood pressure $(n=1)$.

Given the evidence found in the literature, authors' experience, and after extensive and rigorous analysis of the criteria suggested by experts, wechose the following items for assessment: level of consciousness, protection of the airways (coughing and swallowing), nausea, vomiting, oxygen saturation, and surgical procedure. In selecting these items, we sought to meet the maximum requirements of safety, simplicity, and ease of application in clinical practice.

\section{Analysis by experts}

After analysis of face validity, nausea and vomiting indicators were combined, and oxygen saturation and surgical procedure were excluded. Ten out of 16 items included in the first version of the assessment remained in the list, making the final version shorter, more objective, and specific.

The final criteria were then organized in a graph algorithm (Figure 2), by which the positive evaluation of all indicators allows to determine the degree of safety necessary to administer the strategy for thirst relief. The Operating Manual, which presents scientific evidence and assists the professional in the evaluation of each security item, was also prepared (Appendix).

Safety Protocol for Thirst Management in the immediate postoperative period (SPTM) In presence of thirst, perform the clinical assessment following the itens below:

LEVEL OF CONSCIOUSNESS
( ) Conscious, alert: Talks, verbalizes thirst, has consistent answers and is oriented.
( ) Drowsy: Wakes uo after verbal command, makes eye contact and has understandable verbal
response, going back to sleep after the end of stimulus.
AIRWAY PROTECTION
( ) Coughs to verbal command; breathes in and uses the thoracic and abdominal muscles, expelling
high air flow.
( ) Does not cough with verbal command.
( ) Swallows voluntarily or with verbal command.
( ) Does not swallow with verbal command.
NAUSEA AND VOMITING

( ) No nausea complaints.

( ) Complains of nausea.

( ) No vomiting.

( ) Is vomiting.
Operating Procedures

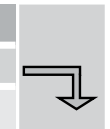

Procedures to be carried out for assessing every item of the SPTM

\section{Observe if patient is awake.}

2. Ask if patient is thirsty.

3. Ask:

- What is your name? Where are you?

4. Wait 15 seconds without stimulating the patient, observing if he/she does

1. Place your hands on abdomen and chest of the patient.

2. Ask the patient to cough.

3. Evaluate use of abdominal and thoracic muscles during cough.

4. Observe expulsion of hig air flow.

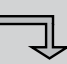

2. Check if patient can obey the command.

3. Observe the elevation of the larynx during swallowing.

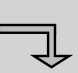

1. Ask the patient about the presence of nausea.

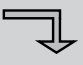

1. Question the patient and observe the presence of vomiting not go back to sleep.

1. Ask the patient to swallow.

Figure 2 - Safety Protocol for the Management of Thirst - southern Brazil, 2013.

The lanes in dark tone and titles in bold (dark green tone in the SPTM) represent the indicator being assessed. The lane with a clear tone (light green tone in the SPTM) represents the safety criterion (rule of thumb) required to determine whether the evaluation may progress through the following steps of the protocol. The clearer tone lanes (light yellow in the SPTM) represent the cutting criterion, indicating that the patient clinical condition is not safe for administration thirst relief strategies. During clinical assessment, it should be emphasized that identification of a condition different from the first established in each safety criterion signals for interruption in the protocol use. After a period that allows realizing a change in the clinical status of the patient, a new assessment should be initiated.
After the judges analyzed the protocol, they suggested including a session that describes the necessary steps for its implementation. Thus, Operational Procedures were developed and added to the protocol to standardize evaluation of each criterion. After the contents were validated (not described here), the final protocol was presented (Figure 2).

\section{Semantic analysis}

The groups of nurses and nursing assistants found no difficulty in interpreting the items; minor changes were made only in the order of sentences. The schematic design of the SPTM, its colors, and direction by arrows were analyzed, being well understood by all. The Operating Manual is shown in the Appendix. 


\section{DISCUSSION}

As this study presents a novel approach regarding a construct that has been insufficiently researched, development of a protocol for patient safety was not an easy task. However, we do hope that its application be the beginning of a scientific evidence-based management of thirst. Both the definition of safety criteria and development of a protocol to assess the clinical condition of patients, bring subsidies so that the professional can manage thirst relief using a chosen strategy.

This study has allowed us to see that the criteria used by professionals who are in charge of releasing a strategy for thirst relief were diverse and subjective. It was observed that there were wide criteria and they were generally nonspecific in the assessment of patient safety in the management of thirst. This stems mainly from the state of knowledge about perioperative thirst and its scientific evidence, which are still insufficient for a safe management of thirst.

Different professionals gave their opinions or had contradictory beliefs about the possibility of releasing the use of a strategyfor thirst relief. Sometimes they argued that the type of procedure and the affected site determine the release of using some strategy for thirst relief, as in the case of abdominal surgery, when this practice would bepractice would be prohibited. In other situations, they considered that regard less of the surgical procedure, the amount of liquid to be administered is small and therefore there would not be a negative repercussion for the patient.

Urine output, skin turgor, and hypotension are related to dehydration, so they are not safety criteria in the strict sense. The need for prolonged postoperative fasting presupposes that bowel rest is important for healing of gastrointestinal anastomoses with less risk, although this assumption is not based on scientific evidence. On the other hand, early feeding brings benefits such as early hospital discharge, less incidence of infectious complications, and cost reduction ${ }^{(15)}$.

Assessment of the item Level of Consciousness, as mentioned by the experts surveyed ( $83 \%)$, it is essential to determine the degree of emergence of the anesthetic state during POI. The level of consciousness is closely related to the return of protective reflexes such as cough and swallowing ${ }^{(16)}$. In the clinical experience, we have observed that patients seem to respond adequately to other safety criteria of the protocol even when they are sleepy. However, we sought to establish a high cutting criterion in order to institute a stringent safety standard at that time. For protocol continuity, patients should therefore remain awake and alert without going back to sleep.

Assessing the Protection of the Airways criterion ensures checking whether the protective reflexes of cough and swallowing returned because they are part of a group of physiological reflexes that prevent bronchopulmonary aspiration of salivary and gastric secretions. Assessing this item is critical because patients remain in dorsal decubitus during anesthetic recovery and they may be still under the effect of both anesthetic and muscle relaxant medication. These reflexes indicate that patients are able to defend himself against a possible broncho pulmonary aspiration ${ }^{(17)}$.

In order to administer a strategy to relieve thirst, absence of nausea and vomiting is primordial. Occurrence of nausea and vomiting in the postoperative period is high and varies in the range $20-30 \%$ in general anesthesia. Nausea and vomiting are associated with worse outcomes, increase in costs and duration of stay, and various other complications that interfere with the recovery of the surgical patient ${ }^{(18)}$.

In practice, we found that several myths interfere with actions of professionals in the management of thirst. We believe that the main one refers to the need to maintain absolute fasting in the IPO, being related to the risk of vomiting and consequent pulmonary aspiration. Thus, the patient remains long periods in absolute fasting extending the discomfort caused by thirst. Validation of an instrument to intentionally assess the presence or absence of nausea or vomiting is an advance in the care of thirsty patients.

Regarding time of procedure and anesthetic technique, scientific evidence that could confirm inclusion of these criteria in the protocol was not found. Release to administer a strategy for thirst relief as proposed in this protocol is linked to a rigorous assessment of the level of consciousness, reflexes protecting the airways, and absence of nausea and vomiting. These criteria are indicated to assess whether patients have or not safe conditions for the management of thirst.

\section{CONCLUSION}

Assessment of level of consciousness, protection of the airways (cough and swallowing), and absence of nausea and vomiting were the safety criteria selected for the SPTM. These criteria allowassessing safety in the management of thirst and were grouped into aneasy to understand graph algorithm. The operating manual was developed on the basis of an extensive literature review on each of the criteria. In addition, operational procedures were indicated in each phase of the protocol thus standardizing its application. Regarding semantic analysis and pre-test of the protocol, experts and groups showed that it is easy to understand and quick to apply.

It should be mentioned that lack of studies that could guide the development of action protocols in nursing hampered this study. We hope that this study can support and encourage other investigators who need to develop other action protocols.

This Safety Protocol for Thirst Management is propiciates further studies on the management of a discomfort as common and intense as thirst in the immediate postoperative period.
Development of a Safety protocol for Management Thirst in the Immediate Postoperative Period Nascimento LA, Fonseca LF, Rosseto EG, Santos CB 


\section{REFERENCES}

1. Leiper J. Thirst. In: Caballero B, Allen L, Prentice A. Encyclopedia of human nutrition. 2nd. ed. Aberdeen (UK): Elsevier; 2005. p. 278-86.

2. Arai S, Stotts N, Puntillo K. Thirst in critically ill patients: from physiology to sensation. Am J Crit Care [Internet]. 2013 [cited 2013 Aug 10];22(4):328-35. Available from: http://www.ncbi. nlm.nih.gov/pubmed/23817822

3. Lisboa Gois CF, Maimoni Aguillar O, Santos V, Llapa Rodriguész EO. Stress factors for patients undergoing cardiac surgery. Invest Educ Enferm [Internet]. 2012 [cited 2013 Jun 20];30(3):312-9. Available from: http://www.scielo.org.co/ pdf/iee/v30n3/v30n3a03.pdf

4. Figueredo E, Sánchez G, Pérez J. Thirst is the most common minor complication in the immediate postoperative period. Rev Esp Anestesiol Reanim. 1996;43(2):74.

5. Soler RRS, Sociats IC, Pes AS, Ribas MG, Vila RD. Studio del grado de satisfacción del paciente quirúrgico crítico y sus familiares atendido en una unidad de reanimación post-quirúrgica. Rev Calidad Asistencial. 1993;8(2-3):35-9.

6. Aroni P, Nascimento LA, Fonseca LF. Assessment strategies for the management of thirst in the post-anesthetic recovery room. Acta Paul Enferm [Internet]. 2012 [cited 2013 June 20];25(4):530-6. Available from: http://www.scielo.br/pdf/ ape/v25n4/en_08.pdf

7. Cho EA, Kim KH, Park JY. Effects of frozen gauze with normal saline and ice on thirst and oral condition of laparoscopic cholecystectomy patients: pilot study. J Korean Acad Nurs. 2010;40(5):714-23.

8. Yoon SY, Min HS. The effects of cold water gargling on thirst, oral cavity condition, and sore throat in orthopedics surgery patients. Korean J Rehabil Nurs. 2011;14(2):136-44.

9. Pancieri AP, Santos BP, Ávila MAG, Braga EM. Checklist de cirurgia segura: análise da segurança e comunicação das equipes de um hospital-escola. Rev Gaúcha Enferm [Internet]. 2013 [citado 2013 jun. 25];34(1):71-8. Disponível em: http:// www.seer.ufrgs.br/index.php/RevistaGauchadeEnfermagem/ article/view/33863
10. Whitaker CDK, Booth $\mathrm{H}$, Clyburn $\mathrm{P}$, Harrop-Griffiths W, Hosie $H$, Kilvington $B$, et al.; Association of Anaesthetists of Great Britain and Ireland. Immediate post-anaesthesia recovery 2013: guidelines. Anaesthesia [Internet]. 2013 [cited 2013 Sept 12];68(3):288-97. Available from: http://onlinelibrary. wiley.com/doi/10.1111/anae.12146/pdf

11. Lo Biondo-Wood G, Haber J. Pesquisa em enfermagem: métodos, avaliação crítica e utilização. 4a ed. Rio de Janeiro: Guanabara-Koogan; 2001.

12. Pasquali L. Instrumentos psicológicos: manual prático de elaboração. Brasília: LABPAM/IBAPP; 1999. Testes referentes a constructo: teoria e modelo de construção; p. 37-72.

13. Vituri DW, Matsuda LM. Content validation of quality indicators for nursing care evaluation. Rev Esc Enferm USP [Internet]. 2009 [cited 2013 Nov 25];43(2) :429-37. Available from: http://www.scielo.br/pdf/reeusp/v43n2/en_a24v43n2.pdf

14. Terwee CB, Bot SD, De Boer MR, van der Windt DA, Knol $\mathrm{DL}$, Dekker J, et al. Quality criteria were proposed for measurement properties of health status questionnaires. J Clin Epidemiol. 2007;60(1):34-42.

15. Bankhead R, Boullata J, Brantley S, Corkins M, Guenter P, Krenitsky J, et al. Enteral nutrition practice recommendations. JPEN J Parenter Enteral Nutr. 2009;33(2):122-67.

16. Leder SB, Suiter DM, Lisitano WH. Answering orientation questions and following single-step verbal commands: effect on aspiration status. Dysphagia. 2009;24(3):290-5.

17. Souza TM, Carvalho R, Paldino CM. Diagnósticos, prognósticos e intervenções de enfermagem na sala de recuperação pós-anestésica. Rev SOBECC. 2012;17(4):33-47.

18. Veiga D, Pereira H, Moreno C, Martinho C, Santos C, Abelha F. Postoperative nausea and vomiting: validation of the portuguese version of the postoperative nausea and vomiting intensity score. Rev Bras Anestesiol [Internet]. 2013 [cited 2013 Jan 25];63(4):340-6. Available from: http://www.scielo.br/pdf/rba/v63n4/en_v63n4a06.pdf 


\section{APPENDIX}

\section{Operating Manual of the Safety Protocol for Thirst Management}

\section{Indicator: Assessment of Level of Consciousness.}

Descriptor: Consciousness is defined as the ability of the individual to recognize himself, the environmental stimuli, and respond correctly to these stimuli. Changes in the level of consciousness are related to states of disorientation in time and space, including deep coma. Intermediate states of altered consciousness can also be observed.

Sleepiness or lethargy is a state of decrease in the level of consciousness, in which patients can remain awake with light stimuli, responding verbally in an understandable way but going back to sleep when not stimulated. The American Society of Anesthesiologists (ASA) recommends periodic assessment of patients' mental state during their post-anesthetic recovery for detection and rapid solution of possible complications.

\section{Scientific foundations:}

Practice guidelines for postanesthetic care: a report by the American Society of Anesthesiologists Task Force on Postanesthetic Care. Anesthesiology. 2002;96(3):742-52.

Berger JR. Clinical approach to stupor and coma. In: Bradley WG, Daroff RB, Fenichel GM, Jankovic J. Neurology in clinical practice. Principles of diagnosis and management. 4th ed. Salt Lake: Elsevier; 2004. p. 43-64.

Sociedade Brasileira de Enfermeiros de Centro Cirúrgico, Recuperação Anestésica e Centro de Material e Esterilização (SOBECC). Práticas recomendadas. 6a ed. São Paulo: SOBECC; 2013.

Sources of Information: Assessment of the level of consciousness must cover a description of alertness of patients in response to verbal stimuli. The purpose of this assessment is to determine whether there is any change in the level of consciousness and thus assess the patient regarding safety in administering strategies of thirst relief.

Operational procedures: Observe/whether the patient is awake. Ask whether the patient is thirsty. Ask: What is your name? Where are you? Wait 15 seconds without stimulating the patient, checking whether he/she does not go back to sleep.

Criteria for Assessment Qualification: Patient is conscious, alert: he/she talks, verbalizes thirst, responds consistently, and is oriented; Patient is sleepy: he/she wakes up after a verbal command, makes eye contact, responds verbally in an understandable way, going back to sleep at the end of stimulus.

Frequency of Assessments: Checking the level of consciousness is the first item to be assessed by the Safety Protocol for Management of Thirst in the postoperative period. If the patient is sleepy or if his/her level of cons- ciousness is lowered, stop the protocol and resume assessment after 15 minutes.

\section{Indicator: Protection of the Airways.}

Descriptor: Is a set of physiological mechanisms that work concurrentlywith the purpose of preventing laryngotracheal aspiration (food, saliva or gastric contents led to the trachea). Two mechanisms for protection of the airways, cough and swallowing, were defined for this protocol.

Voluntary or involuntary cough is a reflex for protection of the airways. Their benefits are related to expelling secretions by an increase in the positive pleural pressure, which leads to a compression of the small-caliber airways, producing high flow rate in the airways. It triggers a high expiratory flow, using kinetic energy of the expiratory muscles and elastic recoil of the lungs. There is then a displacement of liquid and solid materials eventually aspirated, which are conducted to the pharynx for later expectoration or swallowing. Effective cough comprises four phases: nervous (irritant receptors in the upper airways capture the stimulus sending it to the bulbar center, from where it returns to trigger the respiratory muscles and glottis); inspiratory (contraction of inspiratory muscles occurs, increasing lung volume and strength of elastic recoil of the lung); compressive (just after the inspiratory phase, the glottis closes and an expiratory effort allows muscles to generate high pressures in the lung); and explosive (after the compression stage, the glottis opens with a high expiratory flow, thereby causing removal of secretions). Cough is considered ineffective when the peripheral receptors, central control of respiratory muscles, or musculoskeletal apparatus are somehow affected by an abnormality.

Swallowing is the displacement of the bolus from the mouth to the stomach in a safe and effective manner. It consists of two phases, which are voluntary and involuntary. The oral phase is voluntary and occurs by preparatory steps during which the food is prepared to be swallowed; the involuntary phase corresponds to the laryngeal and esophageal stages that are automatic and cannot usually be interrupted. Different stimuli initiate the swallowing process - responses to cold stimuli have been better than stimuli near body temperature, especially in structures such as the uvula, tonsils, and palatoglossi arches in their upper portion.

\section{Scientific foundations:}

Guyton AC, Hall JE. Tratado de fisiologia médica. 11aㅡ ed. Rio de Janeiro: Elsevier; 2006.

Lynch CS. Análise da fisiologia da deglutição por meio da ultrassonografia [tese doutorado]. São Paulo: Faculdade de Medicina, Universidade de São Paulo; 2008.
Development of a Safety protocol for Management Thirst in the Immediate Postoperative Period Nascimento LA, Fonseca LF, Rosseto EG, Santos CB 
Pereira NAV, Motta AR, Vicente LCC. Reflexo da deglutição: análise sobre eficiência de diferentes estímulos em jovens sadios. Pró Fono Rev Atualização Científica. 2008;20(3):159-64.

Sociedade Brasileira de Enfermeiros de Centro Cirúrgico, Recuperação Anestésica e Centro de Material e Esterilização (SOBECC). Práticas recomendadas 6a ed. São Paulo: SOBECC; 2013.

Sociedade Brasileira de Pneumologia e Tisiologia. II Diretrizes Brasileiras no Manejo da Tosse Crônica. J Bras Pneumol. 2006;32 Supl. 6:S403-46.

Machado MGR. Bases da fisioterapia respiratória: terapia intensiva e reabilitação. Rio de Janeiro: Guanabara Koogan; 2008.

Sources of Information: Assessment of mechanisms of protection of the airways requires observation of patient's cough on request for him to cough. The following phases of the cough cycle must be observed: inspiration, use of the abdominal and thoracic muscles, and the consequent expulsion with a high flow rate. When a patient does not display the sequential phases of the cycle, he/she must be characterized as patient does not cough.

Assessment of swallowing follows in a manner similar to that of cough. Ask the patient to swallow and it note the movements that are characteristic of the process. If these movements are not present, report that the patient does not swallow.

Operational procedures: Place your hands on the abdomen and thorax of the patient. Ask the patient to cough. Assess the use of abdominal and thoracic muscles during cough. Note the expulsion of a high flow rate.

Criteria for Assessment Qualification: Cough: Patient coughs to a verbal command: Patient inspires and uses the thoracic and abdominal muscles expelling high flow rate; Patient does not cough to a verbal command. Swallowing: Patient swallows voluntarily or to a verbal command; $\mathrm{Pa}$ tient does not swallow.

Frequency of Assessments: Assessment of the mechanisms of protection of the airways covers the second item in the Safety Protocol for Thirst Management in the IPO. If the patient does not cough and/or swallow spontaneously or to a verbal command, then the assessment must be interrupted and resumed in 15 minutes, reassessing the patient from the beginning.

\section{Indicator: Nausea and Vomiting.}

Descriptor: Nausea and vomiting may occur at any time during or after a surgical procedure. They are frequent complications of anesthesia in the postoperative period; currently, their overall incidence remains in the range $20-30 \%$.

The risk for nausea and vomiting could be related to three different factors: the patient, anesthetic technique, and surgical procedure. Both visceral mobilization during surgery and use of anesthetic medication or opioids in the postoperative period often cause nausea and vomiting. Several drugs used in the anesthetic-surgical procedure can cause adverse reactions such as nausea and vomiting. Alfentanil, Remifentanil, Sufentanil, Dopamine hydrochloride Esmolol, Etomidate, Furosemide, Hydrocortisone, Metoprolol, Midazolam, Morphine sulfate, Neostigmine, Halothane, Isoflurane, Nitrous oxide, and Sevoflurane are among such drugs.

Aspiration pneumonia is the most serious complication relating vomiting and anesthesia.

For this reason, fasting is recommended in the preoperative period. However, fasting is often extended for a long time to the postoperative period without need. A gastric volume in the range of $16-36 \mathrm{ml}$ was considered insignificant when correlated with the incidence of nausea and vomiting in the postoperative period, indicating that administration of a small volume of liquid is safe, as proposed in this protocol.

Nausea is described as being muscular contractions of vomiting but without expelling gastric content. It refers to a subjective feeling of the need to vomit. Patients with nausea may or may not vomit.

Vomiting is a serious post-anesthetic complication and occurs by contraction of the diaphragm and abdominal muscles and relaxation of the esophageal sphincter expelling gastric content. If the patient did not yet regain his reflexes of protection of the airways, he/she may aspirate the gastric content and thus have a serious complication. This situation leads to a picture of aspiration pneumonia with a high mortality rate. Recovery is time-consuming and expensive because it occurs partly in the Intensive Care Unit.

The ASA emphasizes that routine assessment and monitoring of nausea and vomiting in the postoperative period to detect complications and reduce the number of adverse outcomes.

\section{Scientific foundations:}

Practice guidelines for postanesthetic care: a report by the American Society of Anesthesiologists Task Force on Postanesthetic Care. Anesthesiology. 2002;96(3):742-52.

Bogossian L. Manual de pré e pós-operatório. 2a ed. Rio de Janeiro: Médica e Científica; 1995.

Guyton AC, Hall JE. Tratado de fisiologia médica. 10 ed. Rio de Janeiro: Guanabara Koogan; 2002.

Lages N, Fonseca C, Neves A, Landeiro M, Abelha FJ. Náuseas e vômitos no pósoperatório: uma revisão do "pequeno grande" problema. Rev Bras Anestesiol. 2005;55(5):575-85.

Omoigui S. Manual de drogas usadas em anestesia. $2^{a}$ ed. São Paulo: Santos; 2001. 
Perlas A, Davis L, Khan M, Mitsakakis N, Chan VW. Gastric sonography in the fasted surgical patient: a prospective descriptive study. Anesth Analg. 2011;113(1):93-7.

Sources of Information: Presence of nausea or vomiting must be assessed by asking the patient. If there is vomiting or a positive response to the presence of nausea, the assessment must be interrupted.

Operational procedures: Ask the patient to swallow. Check whether he/she can swallow to your verbal command. Note elevation of the larynx during swallowing.
Criteria for Assessment Qualification: Presence of nausea and/or vomiting contraindicates administration of ice to relieve thirst. Nausea: Patient does not complain of nausea; Patient complains of nausea. Vomiting: Patient does not vomit; Patient vomits.

Frequency of Assessments: Assessing the presence of nausea and vomiting is part of the third and final stage in the assessment of safety before administeringa strategy of thirst relief The protocol should be discontinued if the patient has vomited or complains of nausea, and it must be restarted from the beginning in 15 minutes. 